\title{
REVIEW
}

Open Access

\section{The effects of resveratrol on lipid profiles and liver enzymes in patients with metabolic syndrome and related disorders: a systematic review and meta-analysis of randomized controlled trials}

Maryam Akbari ${ }^{1}$, Omid Reza Tamtaji ${ }^{2}$, Kamran B. Lankarani ${ }^{3}$, Reza Tabrizi ${ }^{1}$, Ehsan Dadgostar ${ }^{4}$, Neda Haghighat $^{5}$, Fariba Kolahdooz ${ }^{6}$, Amir Ghaderi ${ }^{7,8}$, Mohammad Ali Mansournia ${ }^{9}$ and Zatollah Asemi ${ }^{2^{*}}$ (D)

\begin{abstract}
Background: There are current trials investigating the effect of resveratrol supplementation on lipid profiles and liver enzymes among patients with metabolic syndrome (MetS) and related disorders; however, their findings are controversial. This systematic review and meta-analysis were aimed to determine the effects of resveratrol supplementation on lipid profiles and liver enzymes among patients with MetS and related disorders.

Methods: We performed a comprehensive search of the following online databases up to November 2018: Cochrane Library, PubMed, Embase, and Web of Science. The relevant articles were assessed for quality of studies using the Cochrane risk of bias tool.

Results: Out of 2459 citations, 31 articles were appropriate for including to the current meta-analysis. The pooled results indicated that resveratrol use significantly decreased total cholesterol [weighted mean difference $\left.(\mathrm{WMD})=-7.65 \mathrm{mg} / \mathrm{dL} ; 95 \% \mathrm{Cl},-12.93,-2.37 ; P<0.01 ; I^{2}: 83.4 \%\right]$ and increased gamma-glutamyl transferase (GGT) concentrations (WMD $\left.=1.76 \mathrm{U} / 1 ; 95 \% \mathrm{Cl}, 0.58,2.94 ; P<0.01 ; I^{2}: 20.1 \%\right)$. We found no significant effect of resveratrol supplementation on triglycerides $\left(\mathrm{WMD}=-5.84 \mathrm{mg} / \mathrm{dL} ; 95 \% \mathrm{Cl},-12.68,1.00 ; P=0.09 ; I^{2}\right.$ : 66.8\%), LDL$\left(\mathrm{WMD}=-2.90 \mathrm{mg} / \mathrm{dL} ; 95 \% \mathrm{Cl},-10.88,5.09 ; P=0.47 ; I^{2}: 96.0 \%\right)$, HDL-cholesterol $(\mathrm{WMD}=0.49 \mathrm{mg} / \mathrm{dL} ; 95 \% \mathrm{Cl},-0.80,1.78$; $\left.P=0.45 ; I^{2}: 74.0 \%\right)$, alanine aminotransferase (ALT) (WMD $\left.=-0.14 \mathrm{U} / 1 ; 95 \% \mathrm{Cl},-3.69,3.41 ; P=0.93 ; I^{2}: 79.6 \%\right)$, and aspartate aminotransferase (AST) (WMD $\left.=-0.34 \mathrm{U} / \mathrm{l} ; 95 \% \mathrm{Cl},-2.94,2.27 ; P=0.80 ; I^{2}: 88.0 \%\right)$ concentrations.
\end{abstract}

Conclusions: This meta-analysis demonstrated that resveratrol supplementation among patients with MetS and related disorders significantly reduced total cholesterol and increased GGT concentrations, but did not affect triglycerides, LDL-, HDL-cholesterol, ALT, and AST concentrations. This data suggests that resveratrol may have a potential cardio-protective effect in patients with MetS and related disorders.

Keywords: Resveratrol, Lipid profiles, Liver enzymes, Metabolic syndrome, Meta-analysis

\footnotetext{
*Correspondence: asemi_r@yahoo.com

${ }^{2}$ Research Center for Biochemistry and Nutrition in Metabolic Diseases,

Kashan University of Medical Sciences, Kashan, IR, Iran

Full list of author information is available at the end of the article
}

C The Author(s). 2020 Open Access This article is distributed under the terms of the Creative Commons Attribution 4.0 International License (http://creativecommons.org/licenses/by/4.0/), which permits unrestricted use, distribution, and reproduction in any medium, provided you give appropriate credit to the original author(s) and the source, provide a link to the Creative Commons license, and indicate if changes were made. The Creative Commons Public Domain Dedication waiver (http://creativecommons.org/publicdomain/zero/1.0/) applies to the data made available in this article, unless otherwise stated. 


\section{Background}

Increased concentrations of circulating lipid profiles are a strong risk factor for cardiovascular disease [1]; high concentrations of total-, LDL-cholesterol, or triglycerides, as well as, low concentrations of HDLcholesterol are consistently correlated with incidence of cardiovascular diseases (CVDs) [2, 3]. Metabolic syndrome (MetS) is considered as an insulin resistant syndrome comprising impaired glucose tolerance, decreased insulin sensitivity, dyslipidemia, central obesity, and hypertension, all of which are well- established risk factors for CVDs [4]. In addition, MetS is correlated with non-alcoholic fatty liver disease (NAFLD), type 2 diabetes mellitus (T2DM), colorectal disease, atrial fibrillation and hypothyroidism $[5,6]$. NAFLD is also associated with impaired liver enzymes, including, alanine aminotransferase (ALT) and aspartate aminotransferase (AST), dysfunctional fat cells, and adipose tissue insulin resistance, resulting in hyperglycemia and dyslipidemia $[7,8]$.

The beneficial effects of resveratrol, plant sterols, and stanols on lipid profiles and modifying cardiovascular risk factors have been reported [9-13]. Resveratrol is a natural polyphenolic compound found mainly in peanuts and in the skin of red grapes that is used as a dietary supplement to improve metabolic profiles [14]. The effects of resveratrol supplementation on lipid profiles and liver enzymes have already been evaluated; however, these findings are controversial. In a meta-analysis on seven randomized controlled trials (RCTs), conducted by Sahebkar et al. [15], resveratrol supplementation had no effect on lipid profile. In another meta-analysis conducted by Hausenblas et al. [16], resveratrol supplementation to patients with T2DM was more effective on the systolic blood pressure, hemoglobin A1c, and creatinine, but did not affect fasting glucose, insulin resistance, diastolic blood pressure, insulin, triglycerides, LDL-and HDL-cholesterol concentrations. However, another meta-analysis of then RCTs showed no effects of resveratrol supplementation on total-, LDL-cholesterol, triglycerides, and fasting glucose concentrations [17]. Differences in study design, study population's characteristics, the dosage of resveratrol used, and the duration of intervention might explain the discrepancies among different studies.

We aimed to systematically review the trials investigating the effect of resveratrol supplementation on lipid profiles and liver enzymes and to summarize the impact among patients with MetS and related disorders.

\section{Methods}

PRISMA guideline (ERF) (the preferred reporting items for systematic reviews and meta-analyses) was used to design and implement this meta-analysis.

\section{Search strategy}

Two independent authors (MA and OT) performed a comprehensive search to identify the relevant RCTs through inception up to November 2018. Online databases, including Cochrane Library, PubMed, Embase, and Web of Science databases by using the following $\mathrm{MeSH}$ and text keywords: patients ["Mets" OR "NAFLD" OR "disorders related to MetS" OR "diabetes" OR “T1DM" OR "T2DM" OR "overweight" OR "obese" OR "chronic kidney disease" OR "hypertension" OR "high blood pressure" OR "dyslipidemia" OR "CVD"], intervention ("resveratrols" OR "resveratrol" AND "use" OR "supplementation" OR "intake"), and outcomes lipid profiles ["triglycerides" OR "total cholesterol" OR "LDLcholesterol (LDL-C)" OR "HDL-cholesterol (HDL-C)"] and liver measurements ["alanine aminotransferase (ALT)" OR "aspartate aminotransferase (AST)" OR "gamma-glutamyl transferase (GGT)"]. Clinical trials retrieved that estimated the effect of resveratrol intake on lipid profiles and/or liver enzymes. Our search strategy was limited to human RCTs published in English language. We conducted a manual search in the reference list's included articles and pervious relevant reviews to find other additional articles.

\section{Selection criteria}

The following inclusion criteria were used to select the related articles: RCTs were among humans (with parallel or cross-over design) with metabolic diseases, administrated resveratrol supplements in the intervention group and received placebo in the comparison group, contained sufficient data on mean changes of lipid profiles (including, triglycerides, total-, LDL-, and HDL-cholesterol concentrations), and liver enzymes (ALT, AST, and GGT concentrations), along with standard deviation (SD) or related 95\% confidence intervals (CIs) at the baseline and at the end of trial for the intervention and placebo groups. RCTs which were not placebo controlled or other type of studies including animal, in vitro, case report, and case series, also abstracts or protocols without full texts, and studies with dosage of resveratrol lower than $20 \mathrm{mg} /$ day were excluded.

\section{Data extraction}

Two independent investigators (MA and OT) extracted data using a standard Excel forms according to the following items: first author's name, publication year, country, demographic characteristics of participants, study methods, sample size (intervention/placebo groups), dose of treatment, type of intervention, type of diseases, the mean $\pm(\mathrm{SD})$ of changes for triglycerides, total-, LDL-, HDL-cholesterol, ALT, AST, and GGT concentrations in the intervention and placebo groups at the baseline and at the end of intervention. If the 
outcomes were reported by different doses, types of supplements, or duration of the intervention, we treated each situation as a separate study. Disagreements were resolved by discussion with a third author (ZA).

\section{Quality assessment}

The Cochrane Collaboration risk of bias tool was applied to assess the quality of selected RCTs using the following domains: "randomization generation, allocation concealment, blinding of participants and outcome assessment, incomplete outcome data and selective outcome reporting, and the other sources of bias".

\section{Statistical analysis}

All statistical analyses were conducted using STATA software version 12.0 (Stata Corp., College Station, TX) and RevMan V.5.3 software (Cochrane Collaboration, Oxford, UK). Weighted mean differences (WMDs) and
95\% CIs were considered as the overall combined effect sizes. Heterogeneity across included trials was examined using the Cochrane's $Q$ and $\mathrm{I}^{2}$ statistics. $\mathrm{I}^{2}>50 \%$ with $P<0.05$ indicated that a significant heterogeneity exists, therefore, the DerSimonian and Laird random effects model were used to combine effect sizes; otherwise, the inverse variance fixed-effect model was applied. Sensitivity analyses were performed to evaluate the impact of each included clinical trials on the validity of the overall combined WMDs. Subgroup analyses were conducted to examine the source of heterogeneity according to the following possible moderator variables; type of interventions (resveratrol plus other nutrients or drugs vs. resveratrol alone), dosage of resveratrol ( $>250$ vs. $\leq 250$ $\mathrm{mg} /$ day), duration of intervention ( $\leq 8 \mathrm{vs.}>8$ weeks), and type of chronic condition (e.g. overweight, or obese, or other chronic diseases vs. T2DM). The potential evidence of publication bias was determined using

Articles identified through electronic database search $(\mathrm{n}=2459)$

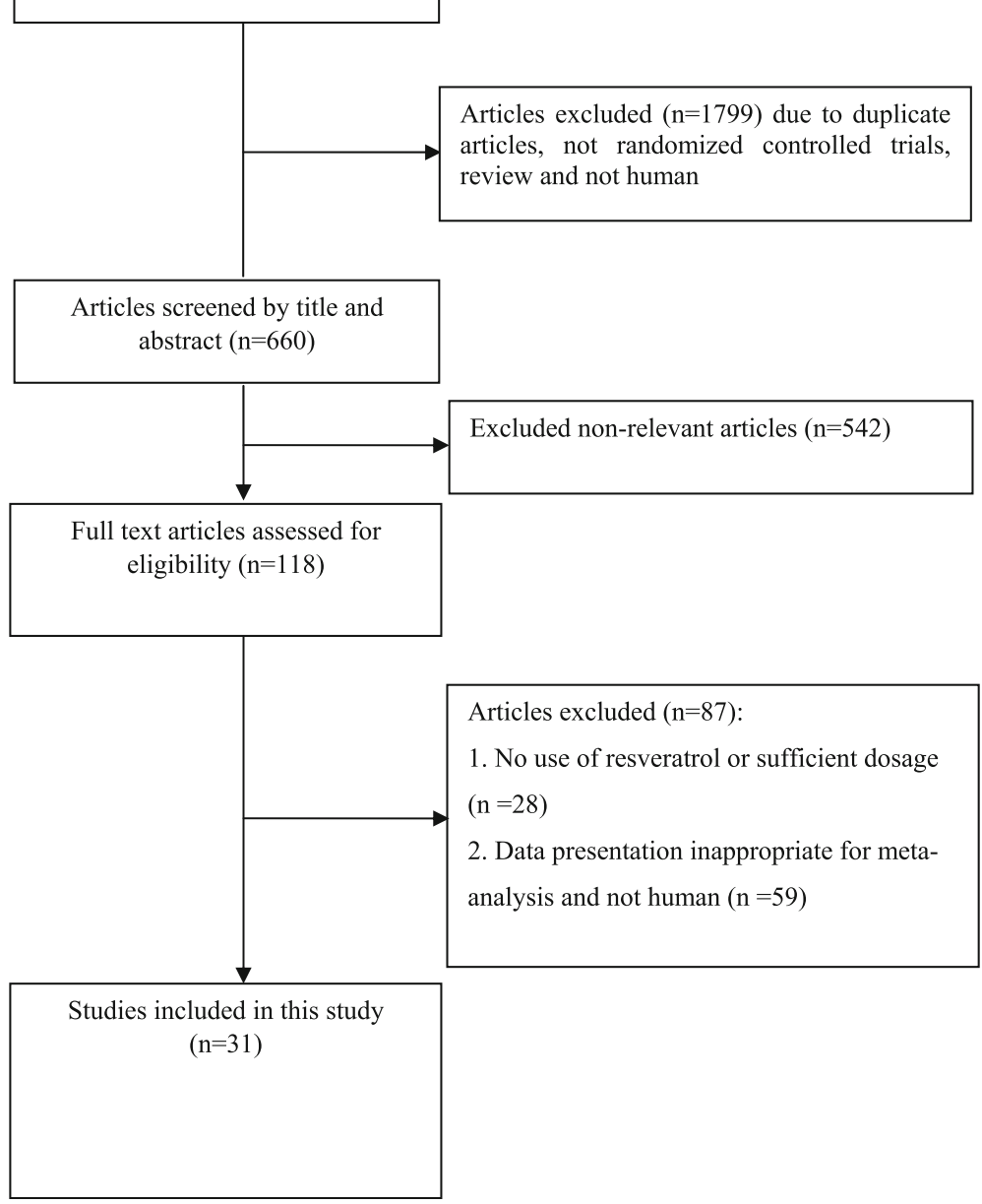

Fig. 1 Literature search and review flowchart for selection of studies 


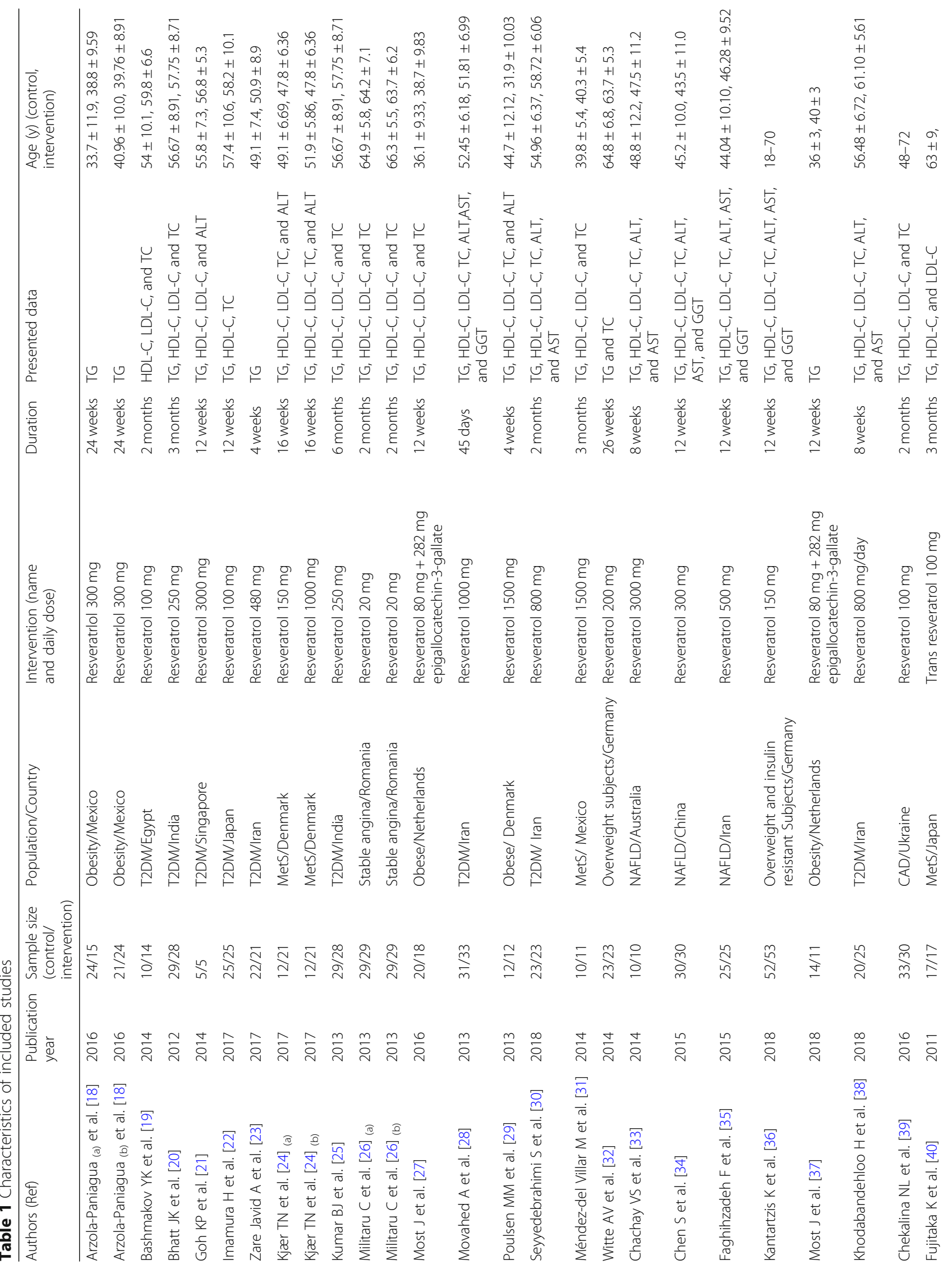




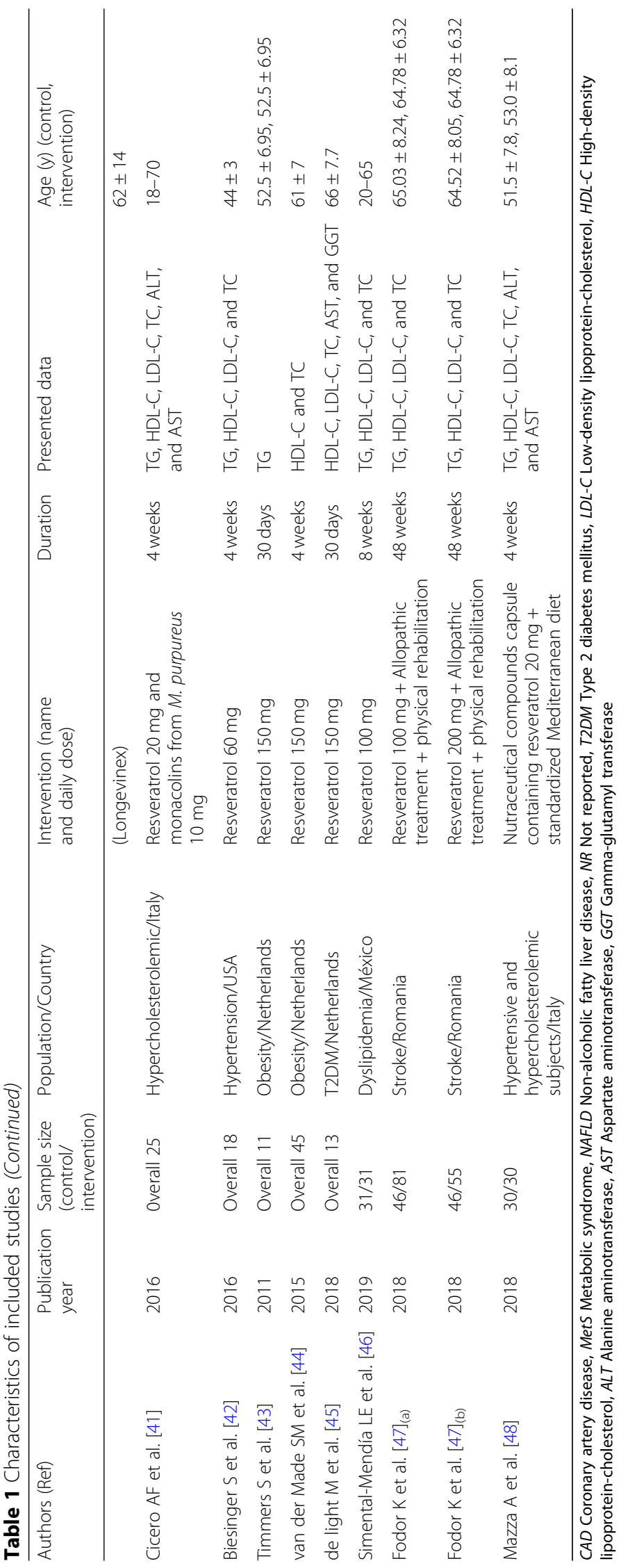


Egger's- and Begg's-test. P-value less than 0.05 were considered as statistically significant.

\section{Results}

In initial online database searches, 2459 reports were identified. After removing duplicates citations by reviewing titles and abstracts and excluding the irrelevant citations, 31 studies (35 effect sizes) were finally included. Figure 1 shows the stepwise with more details of the identification and selection of the relevant articles. All 35 included effect sizes were randomized, placebocontrolled trial. Twenty-nine studies were conducted using parallel design and six studies had cross-over design. The total number of the participants among included studies was 1722 individuals (890 persons in the resveratrol group; and 832 in the placebo group). Thirtytwo studies calculated the influences of resveratrol intake on triglycerides, twenty-eighth on total cholesterol, twenty-seven on LDL-cholesterol, twenty-nine on HDLcholesterol, thirteen on ALT, ten on AST, and five studies on GGT concentrations. The duration of resveratrol supplements ranged from four to 48 weeks and dosage of the intervention varied from 20 to $3000 \mathrm{mg} /$ day among included articles. Table 1 illustrates the characteristics of the included articles. The quality assessment of included articles performed by authors' judgment according to each bias item is presented in Fig. 2 .

\section{Main outcomes}

\section{Effects of resveratrol supplementation on lipid profiles and liver enzymes}

The impact of resveratrol supplementation on lipid profiles and liver enzymes are indicated in Fig. 3. The combined findings, using random-effects model showed that resveratrol intake significantly decreased total cholesterol $(=-7.65 \mathrm{mg} / \mathrm{dL} ; 95 \% \mathrm{CI},-12.93,-2.37 ; P<0.01$; $\left.I^{2}: 83.4 \%\right)$ and increased GGT concentrations (WMD = $\left.1.76 \mathrm{U} / \mathrm{l} ; 95 \% \mathrm{CI}, 0.58,2.94 ; P<0.01 ; \mathrm{I}^{2}: 20.1 \%\right)$. We found no significant effect of resveratrol intake on triglycerides $(\mathrm{WMD}=-5.84 \mathrm{mg} / \mathrm{dL} ; 95 \% \mathrm{CI},-12.68,1.00$; $\left.P=0.09 ; \mathrm{I}^{2}: 66.8 \%\right), \mathrm{LDL}-(\mathrm{WMD}=-2.90 \mathrm{mg} / \mathrm{dL} ; 95 \% \mathrm{CI}$, $\left.-10.88,5.09 ; \quad P=0.47 ; I^{2}: 96.0 \%\right)$, HDL-cholesterol $\left(\mathrm{WMD}=0.49 \mathrm{mg} / \mathrm{dL} ; 95 \% \mathrm{CI},-0.80,1.78 ; P=0.45 ; \mathrm{I}^{2}\right.$ : 74.0\%), ALT (WMD =-0.14 U/l; 95\% CI, $-3.69,3.41$; $\left.P=0.93 ; \mathrm{I}^{2}: 79.6 \%\right)$, and AST $(\mathrm{WMD}=-0.34 \mathrm{U} / \mathrm{l} ; 95 \% \mathrm{CI}$, $\left.-2.94,2.27 ; P=0.80 ; \mathrm{I}^{2}: 88.0 \%\right)$ concentrations.

\section{Subgroup analyses}

The findings of subgroup analyses indicated that there were no significant changes between before and after subgroup analyses combined WMDs for lipid profiles and liver enzymes. The results of subgroup analyses are indicated in Table 2.

\section{Sensitivity analyses}

Sensitivity analyses showed no significant changes between the pre- and post-sensitivity combined WMDs for triglycerides, HDL-cholesterol, ALT, AST, and GGT concentrations. We found that there were a significant effect between before and after sensitivity pooled WMD for total cholesterol after removing Bhatt et al. [20] study (WMD -5.76; 95\% CI, - 12.23, 0.70), and for LDLcholesterol after removing Faghihzadeh et al. [35] study (WMD -6.32; 95\% CI, - 11.41, - 1.22) (Table 3).

\section{Publication bias and quality assessment}

Egger and Begg's tests indicated no significant effect of possible publication bias for meta-analyses calculating the influence of resveratrol intake on triglycerides ( $\mathrm{P}$ Begg's test $=0.74$, P Egger's test $=0.69)$, LDL-cholesterol $\left(\mathrm{P}_{\mathrm{Bg}}=0.07, \quad \mathrm{P}_{\mathrm{Ee}}=0.53\right), \quad$ HDL-cholesterol $\quad\left(\mathrm{P}_{\mathrm{Bg}}=0.88\right.$, $\left.\mathrm{P}_{\mathrm{Ee}}=0.98\right), \operatorname{ALT}\left(\mathrm{P}_{\mathrm{Bg}}=0.39, \mathrm{P}_{\mathrm{Ee}}=0.11\right)$, AST $\left(\mathrm{P}_{\mathrm{Bg}}=0.42\right.$, $\left.\mathrm{P}_{\mathrm{Ee}}=0.90\right)$, and GGT concentrations $\left(\mathrm{P}_{\mathrm{Bg}}=0.14, \mathrm{P}_{\mathrm{Ee}}=\right.$ $0.60)$. The authors found that there was a significant effect of the potential of publication bias for totalcholesterol $\left(\mathrm{P}_{\mathrm{Bg}}=0.17, \mathrm{P}_{\mathrm{Ee}}=0.00\right)$. We applied non-

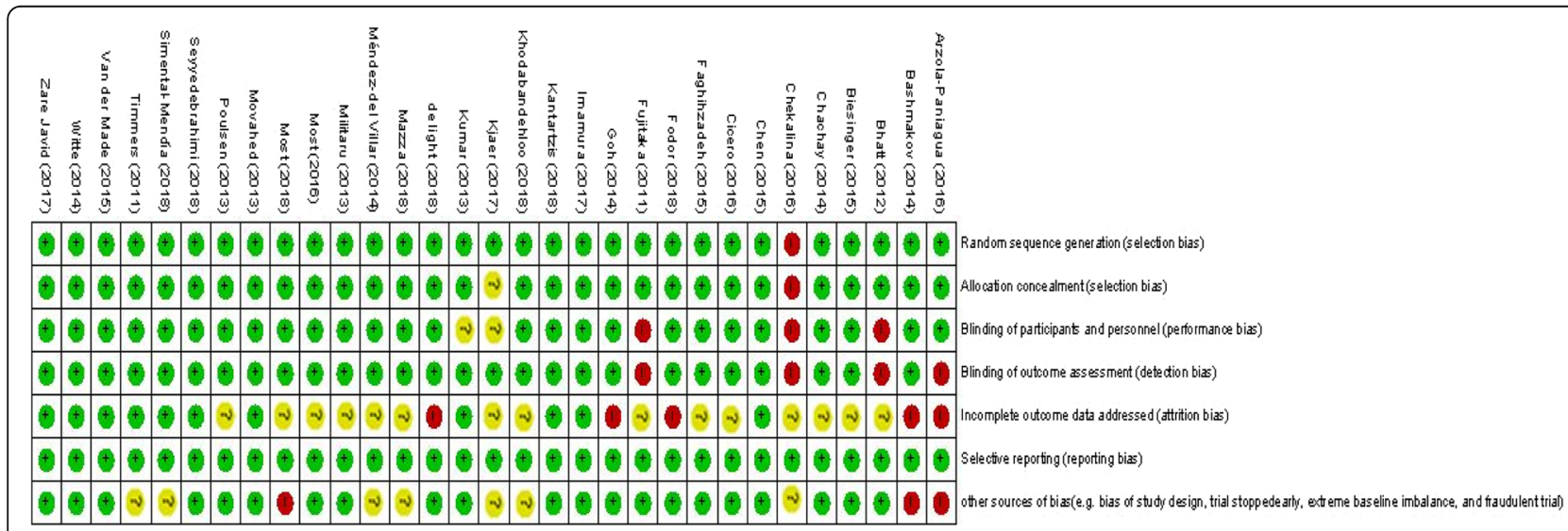

Fig. 2 The summary of review authors' judgments about each risk of bias item for each included study 

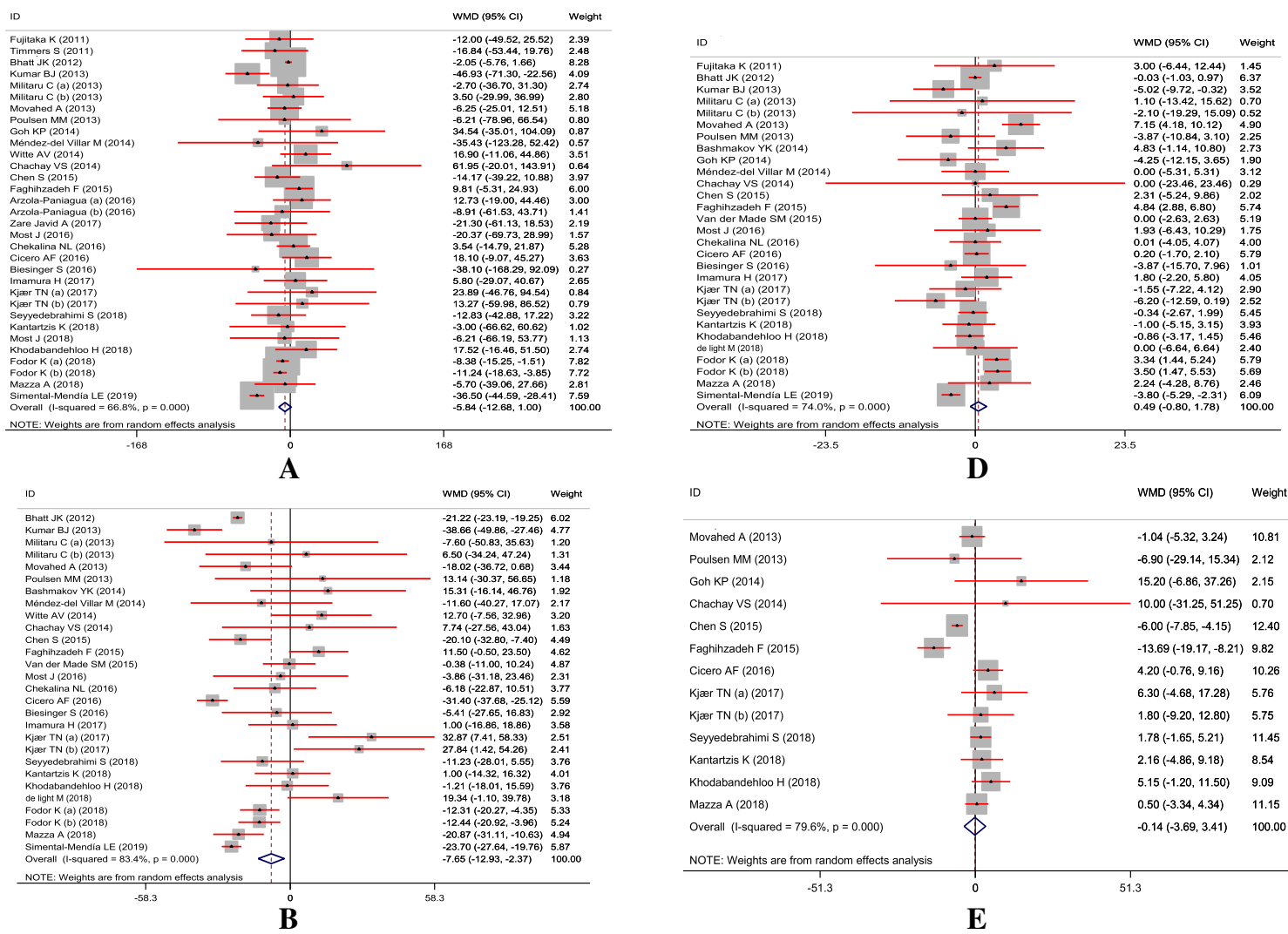

ID

WMD $(95 \% \mathrm{Cl}) \quad$ Weight

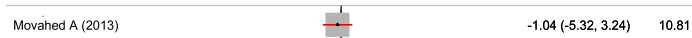
Poulsen MM (2013) Poulsen MM (2013) Goh KP (2014) Chachay vs (2014) Chen S (2015) Faghihzadeh F (2015) Cicero AF (2016) Kjær TN (a) (2017) Kjær TN (b) (2017) Seyyedebrahimi S (2018) Kantartzis K (2018) Khodabandehloo $\mathrm{H}$ (2018) Mazza A (2018) Overall (I-squared $=79.6 \%, p=0.000$ NOTE: Weights are from random effects analysis
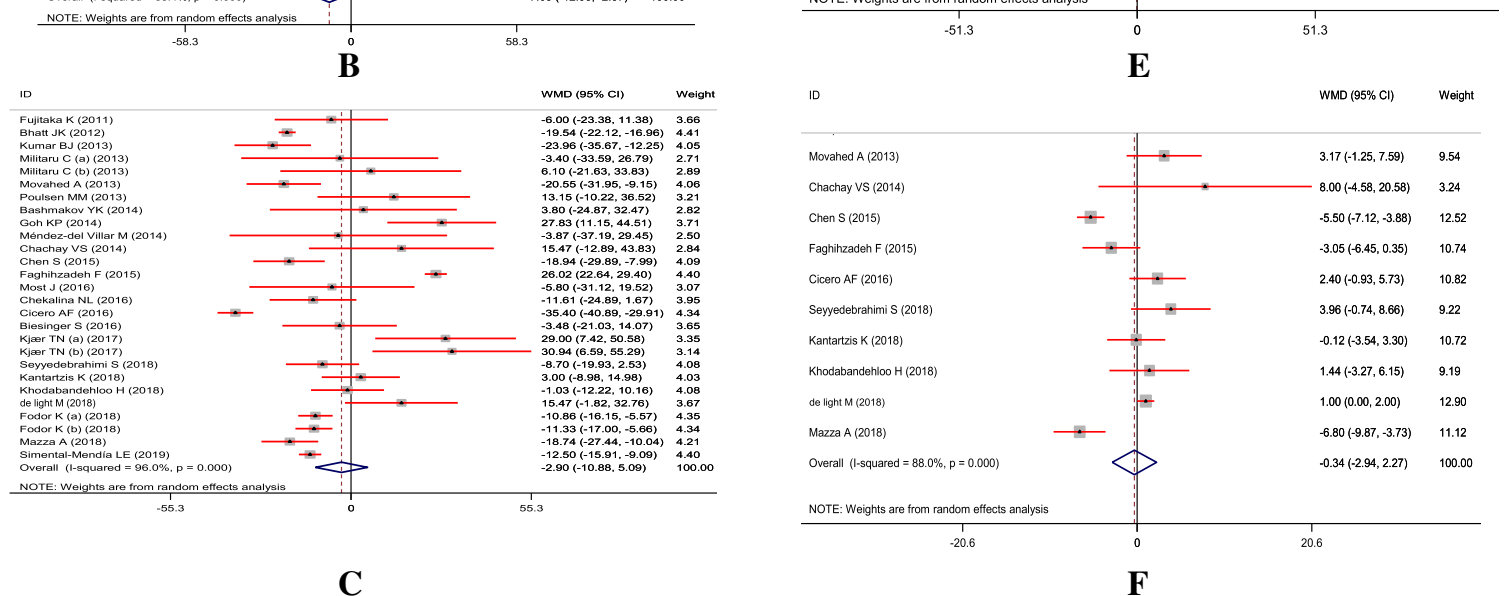

C

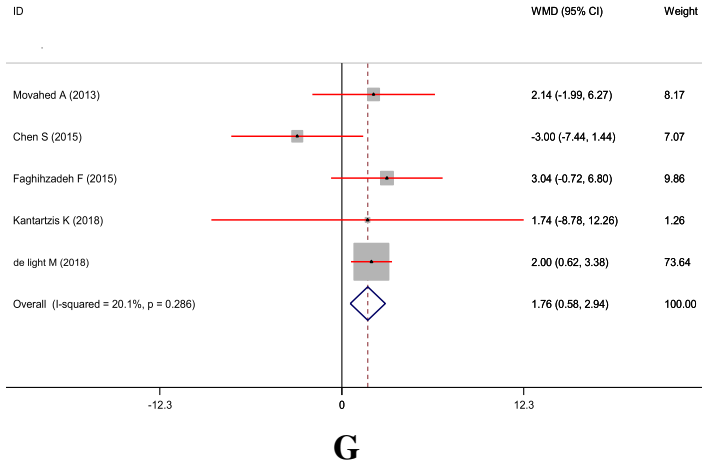

Fig. 3 A-G Meta-analysis standardized mean differences estimates for (a) triglycerides (b) for total-, (c) for LDL-, (d) for HDL-cholesterol, (e) for ALT, (f) for AST, and (g) for GGT concentrations in the resveratrol and control groups $(\mathrm{Cl}=95 \%)$ 
Table 2 The association between resveratrol intake on lipid profiles and liver enzymes using subgroup analysis

\begin{tabular}{|c|c|c|c|c|c|c|c|}
\hline Variables & & $\begin{array}{l}\text { Number of } \\
\text { WMD included }\end{array}$ & Subgroups & $\begin{array}{l}\text { Pooled WMD } \\
\text { (random effect) }\end{array}$ & $95 \% \mathrm{Cl}$ & $1^{2}(\%)$ & Overall $I^{2}(\%)$ \\
\hline \multirow[t]{10}{*}{ Triglycerides } & & 32 & Overall & -5.84 & $-12.68,1.00$ & 66.8 & 66.8 \\
\hline & Type of intervention & 6 & $\begin{array}{l}\text { Resveratrol plus other } \\
\text { nutrients or drugs }\end{array}$ & -8.81 & $-13.67,-3.96$ & 0.0 & \\
\hline & & 26 & Resveratrol & -5.06 & $-14.41,4.29$ & 71.8 & \\
\hline & Dosage of resveratrol (mg/day) & 10 & $\geq 500 \mathrm{mg}$ resveratrol & 1.43 & $-7.84,10.69$ & 0.0 & \\
\hline & & 22 & $<500 \mathrm{mg}$ resveratrol & -8.07 & $-16.20,0.05$ & 74.1 & \\
\hline & Duration of study (week) & 14 & $<12$ weeks & -4.93 & $-19.17,9.31$ & 70.8 & \\
\hline & & 18 & $\geq 12$ weeks & -5.40 & $-11.53,0.74$ & 40.5 & \\
\hline & Type of disease & 8 & Overweight or obese & 1.44 & $-13.46,16.34$ & 0.0 & \\
\hline & & 16 & Other & -5.41 & $-15.72,4.91$ & 74.1 & \\
\hline & & 8 & T2DM & -8.06 & $-21.30,5.17$ & 58.4 & \\
\hline \multirow[t]{10}{*}{ Total cholesterol } & & 28 & Overall & -7.65 & $-12.93,-2.37$ & 83.4 & 83.4 \\
\hline & Type of intervention & 5 & $\begin{array}{l}\text { Resveratrol plus other } \\
\text { nutrients or drugs }\end{array}$ & -18.10 & $-27.80,-8.39$ & 80.5 & \\
\hline & & 23 & Resveratrol & -4.02 & $-10.53,2.49$ & 84.4 & \\
\hline & Dosage of resveratrol (mg/day) & 9 & $\geq 500 \mathrm{mg}$ resveratrol & -2.47 & $-13.62,8.67$ & 64.3 & \\
\hline & & 19 & $<500 \mathrm{mg}$ resveratrol & -10.07 & $-15.81,-4.33$ & 84.2 & \\
\hline & Duration of study (week) & 15 & $<12$ weeks & -8.61 & $-16.64,-0.57$ & 78.5 & \\
\hline & & 13 & $\geq 12$ weeks & -5.29 & $-14.06,3.49$ & 87.6 & \\
\hline & Type of disease & 5 & Overweight or obese & 1.93 & $-5.65,9.50$ & 0.0 & \\
\hline & & 15 & Other & -8.32 & $-16.28,-0.36$ & 83.8 & \\
\hline & & 8 & T2DM & -9.68 & $-21.12,1.76$ & 83.4 & \\
\hline \multirow[t]{10}{*}{ LDL-cholesterol } & & 27 & Overall & -2.90 & $-10.88,5.09$ & 96.0 & 96.0 \\
\hline & Type of intervention & 5 & $\begin{array}{l}\text { Resveratrol plus other } \\
\text { nutrients or drugs }\end{array}$ & -17.61 & $-29.20,-6.01$ & 92.2 & \\
\hline & & 22 & Resveratrol & 0.84 & $-8.72,10.39$ & 96.1 & \\
\hline & Dosage of resveratrol (mg/day) & 10 & $\geq 500 \mathrm{mg}$ resveratrol & 5.47 & $-9.90,20.84$ & 93.8 & \\
\hline & & 17 & $<500 \mathrm{mg}$ resveratrol & -9.89 & $-15.45,-4.33$ & 86.2 & \\
\hline & Duration of study (week) & 14 & $<12$ weeks & -7.38 & $-15.47,0.71$ & 85.9 & \\
\hline & & 13 & $\geq 12$ weeks & 0.59 & $-12.65,13.84$ & 97.6 & \\
\hline & Type of disease & 3 & Overweight or obese & 3.47 & $-6.35,13.29$ & 0.0 & \\
\hline & & 16 & Other & -2.94 & $-14.71,8.82$ & 97.0 & \\
\hline & & 8 & T2DM & -5.10 & $-16.01,5.80$ & 88.1 & \\
\hline \multirow[t]{10}{*}{ HDL-cholesterol } & & 29 & Overall & 0.49 & $-0.80,1.78$ & 74.0 & 74.0 \\
\hline & Type of intervention & 5 & $\begin{array}{l}\text { Resveratrol plus other } \\
\text { nutrients or drugs }\end{array}$ & 2.31 & $0.63,3.98$ & 44.4 & \\
\hline & & 24 & Resveratrol & -0.02 & $-1.52,1.49$ & 73.4 & \\
\hline & Dosage of resveratrol (mg/day) & 10 & $\geq 500 \mathrm{mg}$ resveratrol & 0.55 & $-2.21,3.32$ & 78.2 & \\
\hline & & 19 & $<500 \mathrm{mg}$ resveratrol & 0.31 & $-1.11,1.72$ & 69.1 & \\
\hline & Duration of study (week) & 15 & $<12$ weeks & 0.26 & $-1.66,2.18$ & 72.1 & \\
\hline & & 14 & $\geq 12$ weeks & 0.79 & $-0.92,2.50$ & 71.1 & \\
\hline & Type of disease & 4 & Overweight or obese & -0.46 & $-2.51,1.59$ & 0.0 & \\
\hline & & 16 & Other & 0.61 & $-1.55,2.76$ & 69.3 & \\
\hline & & 9 & T2DM & 0.63 & $-1.43,2.70$ & 74.3 & \\
\hline
\end{tabular}


Table 2 The association between resveratrol intake on lipid profiles and liver enzymes using subgroup analysis (Continued)

\begin{tabular}{|c|c|c|c|c|c|c|c|}
\hline Variables & & $\begin{array}{l}\text { Number of } \\
\text { WMD included }\end{array}$ & Subgroups & $\begin{array}{l}\text { Pooled WMD } \\
\text { (random effect) }\end{array}$ & $95 \% \mathrm{Cl}$ & $1^{2}(\%)$ & Overall $I^{2}(\%)$ \\
\hline \multirow[t]{10}{*}{$\overline{A L T}$} & & 13 & Overall & -0.14 & $-3.69,3.41$ & 79.6 & 79.6 \\
\hline & Type of intervention & 2 & $\begin{array}{l}\text { Resveratrol plus other } \\
\text { nutrients or drugs }\end{array}$ & 2.00 & $-1.56,5.56$ & 25.2 & \\
\hline & & 11 & Resveratrol & -0.74 & $-4.88,3.41$ & 78.9 & \\
\hline & Dosage of resveratrol (mg/day) & 9 & $\geq 500 \mathrm{mg}$ resveratrol & -1.77 & $-6.37,2.84$ & 80.8 & \\
\hline & & 4 & $<500 \mathrm{mg}$ resveratrol & 2.19 & $-0.51,4.89$ & 0.0 & \\
\hline & Duration of study (week) & 7 & $<12$ weeks & 1.52 & $-0.39,3.43$ & 0.0 & \\
\hline & & 11 & $\geq 12$ weeks & -2.01 & $-8.09,4.08$ & 78.2 & \\
\hline & Type of disease & 2 & Overweight or obese & 1.34 & $-5.36,8.04$ & 0.0 & \\
\hline & & 7 & Other & -1.76 & $-7.00,3.48$ & 83.8 & \\
\hline & & 4 & $\mathrm{~T} 2 \mathrm{DM}$ & 1.75 & $-1.43,4.92$ & 27.3 & \\
\hline \multirow[t]{10}{*}{ AST } & & 10 & Overall & -0.34 & $-2.94,2.27$ & 88.0 & 88.0 \\
\hline & Type of intervention & 2 & $\begin{array}{l}\text { Resveratrol plus other } \\
\text { nutrients or drugs }\end{array}$ & -2.22 & $-11.24,6.79$ & 93.7 & \\
\hline & & 8 & Resveratrol & 0.18 & $-2.70,3.05$ & 87.5 & \\
\hline & Dosage of resveratrol (mg/day) & 6 & $\geq 500 \mathrm{mg}$ resveratrol & 0.28 & $-3.78,4.35$ & 84.1 & \\
\hline & & 4 & $<500 \mathrm{mg}$ resveratrol & -0.83 & $-4.42,2.76$ & 87.5 & \\
\hline & Duration of study (week) & 7 & $<12$ weeks & 0.96 & $-1.92,3.84$ & 79.1 & \\
\hline & & 3 & $\geq 12$ weeks & -3.16 & $-6.43,0.12$ & 76.1 & \\
\hline & Type of disease & 1 & Overweight or obese & -0.12 & $-3.54,3.30$ & - & \\
\hline & & 5 & Other & -2.61 & $-6.29,1.06$ & 83.6 & \\
\hline & & 4 & T2DM & 1.23 & $0.30,2.17$ & 0.0 & \\
\hline \multirow[t]{10}{*}{ GGT } & & 5 & Overall & 1.76 & $0.58,2.94$ & 20.1 & 20.1 \\
\hline & Type of intervention & - & $\begin{array}{l}\text { Resveratrol plus other } \\
\text { nutrients or drugs }\end{array}$ & - & - & - & \\
\hline & & 5 & Resveratrol & 1.76 & $0.58,2.94$ & 20.1 & \\
\hline & Dosage of resveratrol (mg/day) & 3 & $\geq 500 \mathrm{mg}$ resveratrol & 1.05 & $-1.31,3.40$ & 55.9 & \\
\hline & & 2 & $<500$ mg resveratrol & 2.00 & $0.63,3.36$ & 0.0 & \\
\hline & Duration of study (week) & 2 & $<12$ weeks & 2.01 & $0.71,3.32$ & 0.0 & \\
\hline & & 3 & $\geq 12$ weeks & 0.60 & $-2.17,3.37$ & 52.2 & \\
\hline & Type of disease & 1 & Overweight or obese & 1.74 & $-8.78,12.26$ & - & \\
\hline & & 2 & Other & 0.52 & $-2.35,3.39$ & 75.8 & \\
\hline & & 2 & $\mathrm{~T} 2 \mathrm{DM}$ & 2.00 & $0.71,3.32$ & 0.0 & \\
\hline
\end{tabular}

ALT Alanine aminotransferase, AST Aspartate aminotransferase, GGT Gamma-glutamyl transferase

parametric method (Duval and Tweedie) to calculate the findings of censored articles for total-cholesterol; however, pooled WMDs findings did not statistically significant change after using Duval and Tweedie test.

\section{Discussion}

The findings of current systematic review and metaanalysis showed that resveratrol supplementation among patients with MetS and related disorders significantly reduced total cholesterol and increased GGT concentrations, but did not affect triglycerides, LDL-, HDLcholesterol, ALT, and AST concentrations.
MetS and related disorders are characterized by changes in fatty acid metabolism, which finally results in decreased HDL-cholesterol, and increased LDL-cholesterol as well as, triglycerides concentrations. As dyslipidemia is a well-established risk factor for MetS, diabetes, and CVDs, circulating lipid profiles are routinely addressed by pharmacotherapy. We found that resveratrol supplementation among patients with MetS and related disorders significantly reduced total cholesterol, but did not affect triglycerides, LDL-, HDL-cholesterol concentrations. Previously, the effects of resveratrol on weight loss [49] and biomarkers of inflammation and oxidative stress among patients with 
Table 3 The association between resveratrol intake and lipid profiles and liver enzymes using sensitivity analyses

\begin{tabular}{|c|c|c|c|c|c|c|c|}
\hline \multirow[t]{2}{*}{ Variables } & \multicolumn{3}{|l|}{ Pre-sensitivity analysis } & \multirow{2}{*}{$\begin{array}{l}\text { Upper \& lower } \\
\text { of effect size }\end{array}$} & \multicolumn{3}{|c|}{ Post-sensitivity analysis } \\
\hline & No. of studies included & $\begin{array}{l}\text { Pooled WMD } \\
\text { (random effect) }\end{array}$ & $95 \% \mathrm{Cl}$ & & $\begin{array}{l}\text { Pooled WMD } \\
\text { (random effect) }\end{array}$ & $95 \% \mathrm{Cl}$ & Excluded studies \\
\hline \multirow[t]{2}{*}{ Triglycerides } & 32 & -5.84 & $-12.68,1.00$ & Upper & -4.24 & $-8.78,0.29$ & Simental-Mendía [46] \\
\hline & & & & Lower & -6.86 & $-13.88,0.15$ & Faghihzadeh [35] \\
\hline \multirow[t]{2}{*}{ Total cholesterol } & 28 & -7.65 & $-12.93,-2.37$ & Upper & -5.76 & $-12.23,0.70$ & Bhatt [20] \\
\hline & & & & Lower & -9.00 & $-14.11,-3.89$ & Faghihzadeh [35] \\
\hline \multirow[t]{2}{*}{ LDL-cholesterol } & 27 & -2.90 & $-10.88,5.09$ & Upper & -1.49 & $-9.36,6.37$ & Cicero [41] \\
\hline & & & & Lower & -6.32 & $-11.41,-1.22$ & Faghihzadeh [35] \\
\hline \multirow[t]{2}{*}{ HDL-cholesterol } & 29 & 0.49 & $-0.80,1.78$ & Upper & 0.69 & $-0.59,1.99$ & Kumar [25] \\
\hline & & & & Lower & 0.17 & $-1.04,1.40$ & Movahed [28] \\
\hline \multirow[t]{2}{*}{ ALT } & 13 & -0.14 & $-3.69,3.41$ & Upper & -0.33 & $-4.10,3.42$ & Kantartzis [36] \\
\hline & & & & Lower & -0.69 & $-4.35,2.96$ & Khodabandehloo [38] \\
\hline \multirow[t]{2}{*}{ AST } & 10 & -0.34 & $-2.94,2.27$ & Upper & 0.42 & $-2.19,3.03$ & Mazza [48] \\
\hline & & & & Lower & -0.77 & $-3.51,1.96$ & Seyyedebrahimi [30] \\
\hline \multirow[t]{2}{*}{ GGT } & 5 & 1.76 & $0.58,2.94$ & Upper & 2.11 & $0.89,3.34$ & Chen [34] \\
\hline & & & & Lower & 1.07 & $-1.22,3.37$ & de Light M [45] \\
\hline
\end{tabular}

ALT Alanine aminotransferase, AST Aspartate aminotransferase, GGT Gamma-glutamyl transferase

MetS [50], and coenzyme Q10 on lipid profiles among patients diagnosed with coronary artery disease [51] were assessed. In a study conducted by Simental-Mendia et al. [46], resveratrol supplementation at a dosage of $100 \mathrm{mg} /$ day for 8 weeks to individuals with dyslipidemia significantly decreased total cholesterol and triglycerides concentrations. In addition, taking resveratrol supplements at a dosage of $300 \mathrm{mg} /$ day for 3 months by patients with non-alcoholic fatty liver disease significantly decreased total- and LDLcholesterol concentrations [34]. The supplementation of resveratrol plus D-chiro-inositol for 60 days among overweight pregnant woman with an increased fasting glucose significantly reduced total-, LDL-cholesterol, and triglycerides concentrations [52]. However, in a meta-analysis conducted by Zhang et al. [53], resveratrol supplementation significantly increased total- and LDL-cholesterol concentrations. In addition, another meta-analysis found no significant effects on lipid variables following the supplementation of resveratrol in patients with T2DM [16]. The hypocholesterolemic effect of resveratrol may be mediated by its phenolic hydroxyls contain that lead to oxidation of the unsaturated fatty acids and decreasing circulating cholesterol [54]. In addition to the beneficial effects of resveratrol on lipid metabolism, the anti-atherosclerotic activity of resveratrol involves enhanced activity of peroxisome proliferator-activated receptor $\alpha$ [55], suppressing platelet aggregation [56], reduced blood pressure [43], and improvement of the endothelial activity [57]. Therefore, it is expected that resveratrol administration among patients with MetS and related disorders exerts a potential cardioprotective impact.
The current meta-analysis demonstrated that taking resveratrol supplements by patients with MetS and related disorders was associated with a significant reduction in GGT, but did not affect ALT and AST concentrations. In a study by Asghari et al. [58], resveratrol supplementation at a dosage of $600 \mathrm{mg} /$ day for 12 weeks to patients with NAFLD did not modify liver enzymes and oxidative/anti-oxidative status. In addition, previous animal studies have claimed that resveratrol protects the liver against steatosis [59] and decreases intracellular lipids in the liver [60]. In another study, Heebøll et al. [61] demonstrated no significant improvement in the intrahepatic lipid content and the circulating concentrations of liver enzymes following resveratrol supplementation at a dosage of $1500 \mathrm{mg} /$ day for 6 months among patients with NAFLD. An 8-week resveratrol supplementation at a dosage of $3000 \mathrm{mg} /$ day, not only failed to show any significant improvements in NAFLD features, but also significantly increased liver enzymes concentrations [33]. Also, Faghihzadeh et al. [62] demonstrated that $500 \mathrm{mg} /$ day resveratrol supplementation for 3 months among people with NAFLD significantly improved liver steatosis and ALT concentrations. A similar study with $600 \mathrm{mg} /$ day resveratrol also documented a significant improvement in liver enzymes concentrations without any changes in liver steatosis degree [34]. These inconsistent findings could be related to the stage of disease, type of diseases, the method of measuring liver fat content, different dosage of resveratrol used, or baseline metabolic characteristics of the participants. 


\section{Conclusions}

This meta-analysis demonstrated that resveratrol supplementation to the patients with MetS and related disorders significantly reduced total cholesterol and increased GGT concentrations, but did not affect triglycerides, LDL-, HDL-cholesterol, ALT, and AST concentrations. Therefore, resveratrol supplementation to patients with MetS and related disorders may have a potential cardioprotective effect through the reduction of total cholesterol and GGT concentrations.

\section{Abbreviations \\ ALT: Alanine aminotransferase; AST: Aspartate aminotransferase CADs: Coronary artery diseases; GGT: Gamma-glutamyl transferase; HDL- C: High-density lipoprotein-cholesterol; LDL-C: Low-density lipoprotein- cholesterol; MetS: Metabolic syndrome; NAFLD: Non-alcoholic fatty liver disease; NR: Not reported; T2DM: Type 2 diabetes mellitus}

\section{Acknowledgements}

The present study was supported by a grant from the Vice-chancellor for Research, SUMS, Shiraz, and Iran.

\section{Authors' contributions}

ZA contributed in conception, design, statistical analysis and drafting of the manuscript. MA, O-RT, K-BL, RT, ED, NH, FK, AG and M-AM contributed in data collection and manuscript drafting. All authors approved the final version for submission. ZA oversaw the study.

\section{Funding}

The present study was founded by a grant from the Vice Chancellor for Research, Shiraz University of Medical Sciences, in Iran.

\section{Availability of data and materials}

The primary data for this study is available from the authors on direct request.

\section{Ethics approval and consent to participate}

This study was considered exempt by the SUMS Institutional Review Board.

\section{Consent for publication}

Not applicable.

\section{Competing interests}

The authors declare that they have no competing interests.

\section{Author details}

${ }^{1}$ Health Policy Research Center, Institute of Health, Student Research Committee, Shiraz University of Medical Sciences, Shiraz, Iran. ${ }^{2}$ Research Center for Biochemistry and Nutrition in Metabolic Diseases, Kashan University of Medical Sciences, Kashan, IR, Iran. ${ }^{3}$ Health Policy Research Center, Shiraz University of Medical Sciences, Shiraz, Iran. ${ }^{4}$ Halal Research Center of IRI, FDA, Tehran, Iran. ${ }^{5}$ Nutrition Research Center, School of Nutrition and Food Sciences, Shiraz University of Medical Sciences, Shiraz, Iran. ${ }^{6}$ Indigenous and Global Health Research, Department of Medicine, University of Alberta, Edmonton, Canada. ${ }^{7}$ Department of Addiction studies, School of Medical, Kashan University of Medical Sciences, Kashan, Iran. ${ }^{8}$ Clinical Research Development Unit-Matini/Kargarnejad Hospital, Kashan University of Medical Sciences, Kashan, IR, Iran. ${ }^{9}$ Department of Epidemiology and Biostatistics, School of Public Health, Tehran University of Medical Sciences, Tehran, Iran.

Received: 1 April 2019 Accepted: 24 January 2020

Published online: 17 February 2020

\section{References}

1. Nelson RH. Hyperlipidemia as a risk factor for cardiovascular disease. Prim Care. 2013;40:195-211.

2. Lemieux I, Lamarche B, Couillard C, Pascot A, Cantin B, Bergeron J, et al. Total cholesterol/HDL cholesterol ratio vs LDL cholesterol/HDL cholesterol ratio as indices of ischemic heart disease risk in men: the Quebec cardiovascular study. Arch Intern Med. 2001:161:2685-92.

3. Lamarche B, Tchernof A, Moorjani S, Cantin B, Dagenais GR, Lupien PJ, et al. Small, dense low-density lipoprotein particles as a predictor of the risk of ischemic heart disease in men. Prospective results from the Quebec cardiovascular study. Circulation. 1997;95:69-75.

4. Lee SW, Lee TY, Yang SS, Tung CF, Yeh HZ, Chang CS. Risk factors and metabolic abnormality of patients with non-alcoholic fatty liver disease: either non-obese or obese Chinese population. Hepatobiliary Pancreatic Dis Int. 2018;17:45-8.

5. Wong W, Wong GL, Tsang SW, Fan T, Chu WC, Woo J, et al. High prevalence of colorectal neoplasm in patients with non-alcoholic steatohepatitis. Gut. 2011:60:829-36.

6. Pagadala MR, Zein CO, Dasarathy S, Yerian LM, Lopez R, McCullough AJ. Prevalence of hypothyroidism in nonalcoholic fatty liver disease. Dig Dis Sci. 2012;57:528-34

7. Puri P, Baillie RA, Wiest MM, Mirshahi F, Choudhury J, Cheung O, et al. A lipidomic analysis of nonalcoholic fatty liver disease. Hepatology. 2007;46:1081-90.

8. Dongiovanni P, Stender S, Pietrelli A, Mancina RM, Cespiati A, Petta S, et al. Causal relationship of hepatic fat with liver damage and insulin resistance in nonalcoholic fatty liver. J Intern Med. 2018:283:356-70.

9. Sahebkar A, Serban MC, Gluba-Brzozka A, Mikhailidis DP, Cicero AF, Rysz J, et al. Lipid-modifying effects of nutraceuticals: an evidence-based approach Nutrition. 2016;32:1179-92.

10. Patti AM, Al-Rasadi K, Giglio RV, Nikolic D, Mannina C, Castellino G, et al. Natural approaches in metabolic syndrome management. Arch Med Sci. 2018;14:422-41.

11. Cicero AFG, Colletti A, Bajraktari G, Descamps O, Djuric DM, Ezhov M, et al Lipid lowering nutraceuticals in clinical practice: position paper from an international lipid expert panel. Arch Med Sci. 2017:13:965-1005.

12. Sosnowska B, Penson $P$, Banach M. The role of nutraceuticals in the prevention of cardiovascular disease. Cardiovasc Diagn Ther. 2017;7:S21-s31.

13. Banach M, Patti AM, Giglio RV, Cicero AFG, Atanasov AG, Bajraktari G, et al. The role of Nutraceuticals in statin intolerant patients. J Am Coll Cardiol. 2018:72:96-118.

14. Hunter PM, Hegele RA. Functional foods and dietary supplements for the management of dyslipidaemia. Nat Rev Endocrinol. 2017;13:278-88.

15. Sahebkar A. Effects of resveratrol supplementation on plasma lipids: a systematic review and meta-analysis of randomized controlled trials. Nutr Rev. 2013;71:822-35

16. Hausenblas HA, Schoulda JA, Smoliga JM. Resveratrol treatment as an adjunct to pharmacological management in type 2 diabetes mellitus-systematic review and meta-analysis. Mol Nutr Food Res. 2015;59:147-59.

17. Sahebkar A, Serban C, Ursoniu S, Wong ND, Muntner P, Graham IM, et al. Lack of efficacy of resveratrol on C-reactive protein and selected cardiovascular risk factors--results from a systematic review and metaanalysis of randomized controlled trials. Int J Cardiol. 2015;189:47-55.

18. Arzola-Paniagua MA, Garcia-Salgado Lopez ER, Calvo-Vargas CG, Guevara-Cruz M. Efficacy of an orlistat-resveratrol combination for weight loss in subjects with obesity: A randomized controlled trial. Obesity (Silver Spring, Md). 2016;24:1454-63.

19. Bashmakov YK, Assaad-Khalil SH, Abou Seif M, Udumyan R, Megallaa M, Rohoma $\mathrm{KH}$, et al. Resveratrol promotes foot ulcer size reduction in type 2 diabetes patients. ISRN Endocrinol. 2014;2014:816307.

20. Bhatt JK, Thomas S, Nanjan MJ. Resveratrol supplementation improves glycemic control in type 2 diabetes mellitus. Nutr Res. 2012;32:537-41.

21. Goh KP, Lee HY, Lau DP, Supaat W, Chan YH, Koh AF. Effects of resveratrol in patients with type 2 diabetes mellitus on skeletal muscle SIRT1 expression and energy expenditure. Int J Sport Nutr Exerc Metab. 2014;24:2-13.

22. Imamura H, Yamaguchi T, Nagayama D, Saiki A, Shirai K, Tatsuno I. Resveratrol Ameliorates Arterial Stiffness Assessed by Cardio-Ankle Vascular Index in Patients With Type 2 Diabetes Mellitus. Int Heart J. 2017;58(4):577-583.

23. Zare Javid A, Hormoznejad R, Yousefimanesh HA, Zakerkish M, Haghighi-Zadeh $\mathrm{MH}$, Dehghan $\mathrm{P}$, et al. The impact of resveratrol supplementation on blood glucose, insulin, insulin resistance, triglyceride, and periodontal markers in type 2 diabetic patients with chronic periodontitis. Phytother Res. 2017;31:108-14.

24. Kjaer TN, Ornstrup MJ, Poulsen MM, Stodkilde-Jorgensen $H$, Jessen N, Jorgensen $\mathrm{JOL}$, et al. No beneficial effects of resveratrol on the metabolic syndrome: a randomized placebo-controlled clinical trial. J Clin Endocrinol Metab. 2017:102:1642-51.

25. Kumar BJ, Joghee NM. Resveratrol supplementation in patients with type 2 diabetes mellitus: a prospective, open label, randomized controlled trial. Int Res J Pharm. 2013;4:246-9. 
26. Militaru C, Donoiu I, Craciun A, Scorei ID, Bulearca AM, Scorei RI. Oral resveratrol and calcium fructoborate supplementation in subjects with stable angina pectoris: effects on lipid profiles, inflammation markers, and quality of life. Nutrition. 2013;29:178-83.

27. Most J, Timmers S, Warnke I, Jocken JW, van Boekschoten M, de Groot P, et al. Combined epigallocatechin-3-gallate and resveratrol supplementation for 12 wk increases mitochondrial capacity and fat oxidation, but not insulin sensitivity, in obese humans: a randomized controlled trial. Am J Clin Nutr. 2016:104:215-27.

28. Movahed A, Nabipour I, Lieben Louis X, Thandapilly SJ, Yu L, Kalantarhormozi $M$, et al. Antihyperglycemic effects of short term resveratrol supplementation in type 2 diabetic patients. Evid Based Complement Alternat Med. 2013:2013:851267.

29. Poulsen MM, Vestergaard PF, Clasen BF, Radko Y, Christensen LP, StodkildeJorgensen $\mathrm{H}$, et al. High-dose resveratrol supplementation in obese men: an investigator-initiated, randomized, placebo-controlled clinical trial of substrate metabolism, insulin sensitivity, and body composition. Diabetes. 2013;62:1186-95

30. Seyyedebrahimi S, Khodabandehloo H, Nasli Esfahani E, Meshkani R. The effects of resveratrol on markers of oxidative stress in patients with type 2 diabetes: a randomized, double-blind, placebo-controlled clinical trial. Acta Diabetol. 2018:55:341-53.

31. Mendez-del Villar M, Gonzalez-Ortiz M, Martinez-Abundis E, Perez-Rubio KG, Lizarraga-Valdez R. Effect of resveratrol administration on metabolic syndrome, insulin sensitivity, and insulin secretion. Metab Syndr Relat Disord. 2014;12:497-501.

32. Witte AV, Kerti L, Margulies DS, Floel A. Effects of resveratrol on memory performance, hippocampal functional connectivity, and glucose metabolism in healthy older adults. J Neurosci. 2014;34:7862-70.

33. Chachay VS, Macdonald GA, Martin JH, Whitehead JP, O'Moore-Sullivan TM, Lee $P$, et al. Resveratrol does not benefit patients with nonalcoholic fatty liver disease. Clin Gastroenterol Hepatol. 2014;12:2092-103 e1-6.

34. Chen S, Zhao X, Ran L, Wan J, Wang X, Qin Y, et al. Resveratrol improves insulin resistance, glucose and lipid metabolism in patients with non-alcoholic fatty liver disease: a randomized controlled trial. Digest Liver Dis. 2015;47:226-32.

35. Faghihzadeh F, Adibi P, Hekmatdoost A. The effects of resveratrol supplementation on cardiovascular risk factors in patients with nonalcoholic fatty liver disease: a randomised, double-blind, placebo-controlled study. Br J Nutr. 2015;114:796-803.

36. Kantartzis K, Fritsche L, Bombrich M, Machann J, Schick F, Staiger $H$, et al. Effects of resveratrol supplementation on liver fat content in overweight and insulin-resistant subjects: a randomized, double-blind, placebocontrolled clinical trial. Diabetes Obes Metab. 2018;20:1793-7.

37. Most J, Warnke I, Boekschoten MV, Jocken JWE, de Groot P, Friedel A, et al. The effects of polyphenol supplementation on adipose tissue morphology and gene expression in overweight and obese humans. Adipocyte. 2018;7:190-6.

38. Khodabandehloo H, Seyyedebrahimi S, Esfahani EN, Razi F, Meshkani R. Resveratrol supplementation decreases blood glucose without changing the circulating CD14(+)CD16(+) monocytes and inflammatory cytokines in patients with type 2 diabetes: a randomized, double-blind, placebocontrolled study. Nutr Res. 2018;54:40-51.

39. Chekalina NI, Kazakov YM, Mamontova TV, Vesnina LE, Kaidashev IP. Resveratrol more effectively than quercetin reduces endothelium degeneration and level of necrosis factor alpha in patients with coronary artery disease. Wiad Lek. 2016;69:475-9.

40. Fujitaka K, Otani H, Jo F, Jo H, Nomura E, Iwasaki M, et al. Modified resveratrol Longevinex improves endothelial function in adults with metabolic syndrome receiving standard treatment. Nutr Res. 2011;31:842-7.

41. Cicero AF, Morbini M, Parini A, Urso R, Rosticci M, Grandi E, et al. Effect of red yeast rice combined with antioxidants on lipid pattern, hs-CRP level, and endothelial function in moderately hypercholesterolemic subjects. Ther Clin Risk Manag. 2016;12:281-6.

42. Biesinger S, Michaels HA, Quadros AS, Qian Y, Rabovsky AB, Badger RS, et al. A combination of isolated phytochemicals and botanical extracts lowers diastolic blood pressure in a randomized controlled trial of hypertensive subjects. Eur J Clin Nutr. 2016;70:10-6.

43. Timmers $\mathrm{S}$, Konings $\mathrm{E}$, Bilet $\mathrm{L}$, Houtkooper $\mathrm{RH}$, van de Weijer T, Goossens $\mathrm{GH}$, et al. Calorie restriction-like effects of 30 days of resveratrol supplementation on energy metabolism and metabolic profile in obese humans. Cell Metab. 2011;14:612-22.

44. van der Made SM, Plat J, Mensink RP. Resveratrol does not influence metabolic risk markers related to cardiovascular health in overweight and slightly obese subjects: a randomized, placebo-controlled crossover trial.PLoS One. 2015;10(3): e0118393. https://doi.org/10.1371/journal.pone.0118393.

45. de Ligt M, Bruls YMH, Hansen J, Habets MF, Havekes B, Nascimento EBM, et al. Resveratrol improves ex vivo mitochondrial function but does not affect insulin sensitivity or brown adipose tissue in first degree relatives of patients with type 2 diabetes. Mol Metab. 2018;12:39-47.

46. Simental-Mendia LE, Guerrero-Romero F. Effect of resveratrol supplementation on lipid profile in subjects with dyslipidemia: a randomized double-blind, placebo-controlled trial. Nutrition. 2019;58:7-10. https://doi.org/10.1016/j.nut.2018.06.015.

47. Fodor K, Tit DM, Pasca B, Bustea C, Uivarosan D, Endres L, et al. Long-term resveratrol supplementation as a secondary prophylaxis for stroke. Oxid Med Cell Longev. 2018;2018:4147320.

48. Mazza A, Schiavon L, Rigatelli G, Torin G, Montanaro F, Lenti S. The shortterm supplementation of monacolin $\mathrm{K}$ improves the lipid and metabolic patterns of hypertensive and hypercholesterolemic subjects at low cardiovascular risk. Food Funct. 2018;9:3845-52.

49. Tabrizi R, Tamtaji OR, Lankarani KB, Akbari M, Dadgostar E, Dabbaghmanesh $\mathrm{MH}$, et al. The effects of resveratrol intake on weight loss: a systematic review and meta-analysis of randomized controlled trials. Crit Rev Food Sci Nutr. 2020;60(3):375-90.

50. Tabrizi R, Tamtaji OR, Lankarani KB, Mirhosseini N, Akbari M, Dadgostar E, et al. The effects of resveratrol supplementation on biomarkers of inflammation and oxidative stress among patients with metabolic syndrome and related disorders: a systematic review and meta-analysis of randomized controlled trials. Food Funct. 2018;9:6116-28.

51. Jorat MV, Tabrizi R, Mirhosseini N, Lankarani KB, Akbari M, Heydari ST, et al. The effects of coenzyme Q10 supplementation on lipid profiles among patients with coronary artery disease: a systematic review and meta-analysis of randomized controlled trials. Lipids Health Dis. 2018;17:230.

52. Malvasi A, Kosmas I, Mynbaev OA, Sparic R, Gustapane S, Guido M, et al. Can trans resveratrol plus $\mathrm{d}$-chiro-inositol and myo-inositol improve maternal metabolic profile in overweight pregnant patients? Clin Ter. 2017;168:e240-e7.

53. Zhang C, Yuan W, Fang J, Wang W, He P, Lei J, et al. Efficacy of resveratrol supplementation against non-alcoholic fatty liver disease: a meta-analysis of placebo-controlled clinical trials. PLoS One. 2016;11:e0161792.

54. Xie HC, Han HP, Chen Z, He JP. A study on the effect of resveratrol on lipid metabolism in hyperlipidemic mice. Afr J Trad Complement Alternat Med AJTCAM. 2014;11:209-12.

55. lannelli P, Zarrilli V, Varricchio E, Tramontano D, Mancini FP. The dietary antioxidant resveratrol affects redox changes of PPARalpha activity. Nutr Metab Cardiovasc Dis. 2007:17:247-56.

56. Shen MY, Hsiao G, Liu CL, Fong TH, Lin KH, Chou DS, et al. Inhibitory mechanisms of resveratrol in platelet activation: pivotal roles of p38 MAPK and NO/cyclic GMP. Br J Haematol. 2007;139:475-85.

57. Zhang H, Zhang J, Ungvari Z, Zhang C. Resveratrol improves endothelial function: role of TNF \{alpha\} and vascular oxidative stress. Arterioscler Thromb Vasc Biol. 2009;29:1164-71.

58. Asghari S, Rafraf M, Farzin L, Asghari-Jafarabadi M, Ghavami SM, Somi MH. Effects of pharmacologic dose of resveratrol supplementation on oxidative/Antioxidative status biomarkers in nonalcoholic fatty liver disease patients: a randomized, double-blind, Placebo-Controlled Trial. Adv Pharm Bull. 2018;8:307-17.

59. Aguirre L, Portillo MP, Hijona E, Bujanda L. Effects of resveratrol and other polyphenols in hepatic steatosis. World J Gastroenterol. 2014;20:7366-80.

60. Shiozaki M, Hayakawa N, Shibata M, Koike M, Uchiyama Y, Gotow T. Closer association of mitochondria with lipid droplets in hepatocytes and activation of Kupffer cells in resveratrol-treated senescence-accelerated mice. Histochem Cell Biol. 2011;136:475-89.

61. Heeboll S, Kreuzfeldt M, Hamilton-Dutoit S, Kjaer Poulsen M, StodkildeJorgensen $\mathrm{H}$, Moller HJ, et al. Placebo-controlled, randomised clinical trial: high-dose resveratrol treatment for non-alcoholic fatty liver disease. Scand J Gastroenterol. 2016;51:456-64.

62. Faghihzadeh F, Adibi P, Rafiei R, Hekmatdoost A. Resveratrol supplementation improves inflammatory biomarkers in patients with nonalcoholic fatty liver disease. Nutr Res. 2014;34:837-43.

\section{Publisher's Note}

Springer Nature remains neutral with regard to jurisdictional claims in published maps and institutional affiliations. 